\title{
Correction to: MYC: a multipurpose oncogene with prognostic and therapeutic implications in blood malignancies
}

Seyed Esmaeil Ahmadi ${ }^{1}$, Samira Rahimi ${ }^{1}$, Bahman Zarandi ${ }^{1}$, Rouzbeh Chegeni ${ }^{2^{*}}$ and Majid Safa ${ }^{1,3^{*}}$

\section{Correction to: J Hematol Oncol (2021) 14:121} https://doi.org/10.1186/s13045-021-01111-4

The original article [1] incorrectly states that OMO-1 is a MYC inhibitor in two instances: in the Direct MYC Inhibition sub-section of the MYC Inhibitors section, and in Table 3.

The authors wish to clarify that OMO-1 is not a MYC inhibitor, and its mentions in the original article should be disregarded.

\section{Author details}

'Department of Hematology and Blood Banking, Faculty of Allied Medicine, Iran University of Medical Sciences, Tehran, Iran. ${ }^{2}$ Medical Laboratory Sciences Program, College of Health and Human Sciences, Northern Illinois University, DeKalb, IL, USA. ${ }^{3}$ Cellular and Molecular Research Center, Iran University of Medical Sciences, Tehran, Iran.

Published online: 03 September 2021

\section{Reference}

1. Ahmadi SE, et al. MYC: a multipurpose oncogene with prognostic and therapeutic implications in blood malignancies. J Hematol Oncol. 2021;14:121. https://doi.org/10.1186/s13045-021-01111-4.

\section{Publisher's Note}

Springer Nature remains neutral with regard to jurisdictional claims in published maps and institutional affiliations.

*Correspondence: rchegeni@niu.edu; safa.m@iums.ac.ir

${ }^{1}$ Department of Hematology and Blood Banking, Faculty of Allied

Medicine, Iran University of Medical Sciences, Tehran, Iran

2 Medical Laboratory Sciences Program, College of Health and Human

Sciences, Northern Illinois University, DeKalb, IL, USA

Full list of author information is available at the end of the article

(c) The Author(s) 2021. Open Access This article is licensed under a Creative Commons Attribution 4.0 International License, which permits use, sharing, adaptation, distribution and reproduction in any medium or format, as long as you give appropriate credit to the original author(s) and the source, provide a link to the Creative Commons licence, and indicate if changes were made. The images or other third party material in this article are included in the article's Creative Commons licence, unless indicated otherwise in a credit line to the material. If material is not included in the article's Creative Commons licence and your intended use is not permitted by statutory regulation or exceeds the permitted use, you will need to obtain permission directly from the copyright holder. To view a copy of this licence, visit http://creativecommons.org/licenses/by/4.0/. The Creative Commons Public Domain Dedication waiver (http://creativecommons.org/publicdomain/zero/1.0/) applies to the data made available in this article, unless otherwise stated in a credit line to the data. 